\title{
Review Article \\ Reproductive Factors but Not Hormonal Factors Associated with Thyroid Cancer Risk: A Systematic Review and Meta-Analysis
}

\author{
Yijuan Cao, ${ }^{1}$ Zengyan Wang, Juan Gu, ${ }^{1}$ Fangfang Hu, ${ }^{1}$ Yujuan Qi, ${ }^{1}$ Qianqian Yin, \\ Qingqing Sun, ${ }^{1}$ Guotao $\mathrm{Li}^{3}{ }^{3}$ and Bin Quan ${ }^{4}$ \\ ${ }^{1}$ Reproductive Center, Central Hospital of Xuzhou, Affiliated Xuzhou Hospital of Southeast University, Xuzhou 221009, China \\ ${ }^{2}$ Department of Anesthesia, People's Hospital of Zhucheng, Zhucheng 262200, China \\ ${ }^{3}$ Reproductive Center, The Affiliated Hospital of Weifang Medical University, Weifang 261000, China \\ ${ }^{4}$ Department of General Surgery, Central Hospital of Xuzhou, Affiliated Xuzhou Hospital of Southeast University, \\ Xuzhou 221009, China
}

Correspondence should be addressed to Yijuan Cao; 15996250339@126.com, Guotao Li; guotao_2000@yeah.net, and Bin Quan; bqsurgery@126.com

Received 4 October 2014; Accepted 16 March 2015

Academic Editor: Ondrej Topolcan

Copyright (C) 2015 Yijuan Cao et al. This is an open access article distributed under the Creative Commons Attribution License, which permits unrestricted use, distribution, and reproduction in any medium, provided the original work is properly cited.

\begin{abstract}
Many studies have investigated the association between hormonal and reproductive factors and thyroid cancer risk but provided contradictory and inconclusive findings. This review was aimed at precisely estimating this association by pooling all available epidemiological studies. 25 independent studies were retrieved after a comprehensive literature search in databases of PubMed and Embase. Overall, common hormonal factors including oral contraceptive and hormone replacement therapy did not alter the risk of thyroid cancer. Older age at menopause was associated with weakly increased risk of thyroid cancer in overall analysis $(\mathrm{RR}=$ $1.24,95 \%$ CI 1.00-1.53, $P=0.049$ ); however, longer duration of breast feeding was related to moderately reduced risk of thyroid cancer, suggested by pooled analysis in all cohort studies $(\mathrm{RR}=0.7,95 \% \mathrm{CI} 0.51-0.95, P=0.021)$. The pooled RR in hospitalbased case-control studies implicated that parous women were more susceptible to thyroid cancer than nulliparous women (RR $=$ 2.30, 95\% CI 1.31-4.04, $P=0.004)$. The present meta-analysis suggests that older age at menopause and parity are risk factors for thyroid cancer, while longer duration of breast feeding plays a protective role against this cancer. Nevertheless, more relevant epidemiological studies are warranted to investigate roles of hormonal and reproductive factors in thyroid carcinogenesis.
\end{abstract}

\section{Introduction}

Thyroid cancer is the most common type of endocrine malignancy, which accounts for nearly $3 \%$ of all malignancies [1]. Despite low mortality rate, rates of local recurrence and distant metastases are high in thyroid cancer patients. The incidence of thyroid cancer has been increasing worldwide for the last five years, while the etiology remains largely unknown. Ionizing radiation is a well documented risk factor for thyroid cancer [2]. However, not all individuals exposed to radiation develop this disease, implicating some other unknown factors involved in thyroid carcinogenesis, such as hormone-related factors.
Gender discrepancy is well known in thyroid malignancies. Thyroid cancer occurs three times more frequently in women than in men, and the incidence decreases among postmenopausal women. It has been well established that female sex hormones, particularly estrogens, can influence the proliferation and invasion of thyroid cancer cells by recognizing corresponding hormonal receptors expressed in those cells, such as estrogen receptor alpha and beta [3-5]. It has been demonstrated that the secretion of thyroid stimulating hormone (TSH) increased during puberty, pregnancy, and oral contraceptive use [6]. Elevated TSH production can promote thyroid growth, while estrogens increase levels of TSH 
in human body [7]. Therefore, regulation between TSH and estrogens may play a critical role in the development of thyroid disease, thyroid malignancies in particular. Taken together, it can be hypothesized that some hormonal and reproductive factors may confer modifying effects on thyroid carcinogenesis by influencing the signaling of sex hormones and their receptors in thyroid gland. Many epidemiological studies have investigated roles of hormonal and reproductive factors in the development of thyroid cancer, for instance, oral contraceptive use, hormone replacement therapy, menstrual factors, and fertility status [8-32]. Nevertheless, the precise association has not yet been fully elucidated due to conflicting and inconclusive findings in previous studies. We performed this meta-analysis by pooling all currently published studies to obtain a better estimation and provide important insights into the etiology of thyroid cancer.

\section{Materials and Methods}

2.1. Search Strategy. We searched studies on the association between hormonal and reproductive factors and thyroid cancer risk in PubMed and Embase databases from their inception up to September 10, 2014, using the following items: thyroid cancer, or thyroid carcinoma; and oral contraceptive, hormone replacement therapy, reproductive factors, menstrual factors, age at menarche, age at first birth, menopausal status, age at menopause, parity, pregnancy, reproductive history, or breast feeding; and incidence, or risk factor. References of relevant studies were also screened for additional papers. If studies were duplicated, only the most complete study was included.

2.2. Inclusion Criteria. The included studies must conform to the following inclusion criteria: (1) studies on the association of hormonal and reproductive factors with thyroid cancer risk; (2) cohort or case-control studies; (3) publications presenting odds ratios (ORs), relative risks (RRs), or hazard ratios (HRs) with 95\% confidence intervals (95\% CIs). Studies not associated with hormonal and reproductive factors and thyroid cancer risk, case-only, animal research, case reports, and duplicated studies were all excluded.

2.3. Data Extraction. Two investigators independently extracted data from each study by use of the following terms: name of first author, year of publication, study design, country of origins, sample size, study period, matching or adjusted factors, and RRs or HRs or ORs with 95\% CIs for the estimation of thyroid cancer risk related to hormonal and reproductive factors. Disagreements were solved by discussion.

2.4. Statistical Analysis. Roles of hormonal and reproductive factors in thyroid cancer risk were assessed by calculating pooled RRs with 95\% CIs by use of STATA 12.0 software (StataCorp, College Station, TX, USA). $P<0.05$ was suggested to be statistically significant. The between-study heterogeneity was estimated by Cochran's $Q$ and $I^{2}$ tests, and $P<0.05$ and $I^{2}>50 \%$ implicated obvious between-study heterogeneity $[33,34]$. The random-effects model was used when the between-study heterogeneity was significant [35]; otherwise, the fixed-effects model was adopted [36]. Stratified analysis by study design (cohort studies, population-based case-control studies, and hospital-based case-control studies) was also performed. Sensitivity analysis by omission of each study was conducted for further analysis. Publication bias risk was evaluated by both Begg's funnel plots and Egger's test $[37,38]$.

\section{Results}

3.1. Identification and Characteristics of Studies Included into the Meta-Analysis. 112 studies were retrieved after a comprehensive literature in databases of PubMed and Embase. However, 87 studies were excluded due to irrelevance, reviews, animal research, and case reports. 25 independent studies on the association between hormonal and reproductive factors and thyroid cancer risk were finally included into our study [8-32]. Among the 25 studies, 13 were cohort studies, 10 were population-based case-control studies, and the other 2 were hospital-based case-control studies. Characteristics of all included studies were summarized in Table 1.

\subsection{Association between Hormonal Factors and Thyroid} Cancer Risk. The common hormonal factors including oral contraceptive and hormone replacement therapy did not modify the risk of thyroid cancer (for oral contraceptive: $\mathrm{RR}=0.94$, 95\% CI $0.85-1.04, P=0.215$; for hormone replacement therapy: $\mathrm{RR}=1.04,95 \% \mathrm{CI} 0.91-1.19, P=0.527$ ) (Table 2). Sensitivity analysis by sequential omission of each study confirmed the findings (data not shown).

Stratified analysis by study design showed that no significant relationship was observed between hormonal factors and thyroid cancer risk in cohort studies and studies in population-based case-control design (Table 2). We failed to perform stratified analysis in hospital-based case-control studies because of insufficient published studies.

3.3. Association between Reproductive Factors and Thyroid Cancer Risk. The pooled RRs revealed that older age at menopause was associated with weakly increased risk of thyroid cancer in overall analysis $(\mathrm{RR}=1.24$, 95\% CI 1.00$1.53, P=0.049$ ) (Table 2; Figure 1), whereas longer duration of breast feeding was related to moderately reduced risk of thyroid cancer in cohort studies ( $\mathrm{RR}=0.7$, 95\% CI $0.51-$ $0.95, P=0.021$ ) (Table 2; Figure 2). Stratified analysis in hospital-based case-control studies showed that more parity could increase the risk of thyroid cancer $(\mathrm{RR}=2.30,95 \%$ CI 1.31-4.04, $P=0.004$ ) (Table 2; Figure 3). No significant relationship was observed between thyroid cancer risk and other common reproductive factors (Table 2). Sensitivity analysis did not materially alter the pooled results (data not shown).

3.4. Heterogeneity Analysis and Publication Bias Risk. No significant between-study heterogeneity was found in most comparisons of overall and stratified analyses, except for 
TABLE 1: Characteristics of all epidemiological studies.

\begin{tabular}{|c|c|c|c|c|c|c|}
\hline First author & Year & Origin & Time & Study design ${ }^{\S}$ & Hormonal or reproductive factors & Adjusted or matching criteria \\
\hline Högnäs [13] & 2014 & Finland & $1974-2010$ & Cohort study & Parity & Sex \\
\hline $\begin{array}{l}\text { Zamora-Ros } \\
{[31]}\end{array}$ & 2015 & Europe & 1992-2009 & Cohort study & $\begin{array}{l}\text { Oral contraceptive, hormone } \\
\text { replacement therapy, age at } \\
\text { menarche, parity, age at first birth, } \\
\text { menopausal status, age at } \\
\text { menopause, breastfeeding status, } \\
\text { and duration of breastfeeding }\end{array}$ & Sex, center, and age at recruitment \\
\hline Braganza [8] & 2014 & USA & 1993-2009 & Cohort study & $\begin{array}{l}\text { Oral contraceptive, hormone } \\
\text { replacement therapy, age at } \\
\text { menarche, parity, age at first birth, } \\
\text { and age at menopause }\end{array}$ & $\begin{array}{l}\text { Sex, education, race, marital status, } \\
\text { family history of thyroid cancer, } \\
\text { baseline body mass index, and } \\
\text { smoking }\end{array}$ \\
\hline Islami [15] & 2013 & Iran & $2003-2007$ & PCC & Parity & $\begin{array}{l}\text { Age, sex, and neighborhood of } \\
\text { residence }\end{array}$ \\
\hline Kabat [16] & 2012 & USA & 1993-2011 & Cohort study & $\begin{array}{l}\text { Oral contraceptive, hormone } \\
\text { replacement therapy, age at } \\
\text { menarche, parity, age at first birth, } \\
\text { age at menopause, and duration of } \\
\text { breastfeeding }\end{array}$ & $\begin{array}{l}\text { Sex, age, education, height, history } \\
\text { of goiter/nodules, pack-years, and } \\
\text { alcohol intake }\end{array}$ \\
\hline $\begin{array}{l}\text { Schonfeld } \\
{[27]}\end{array}$ & 2011 & USA & 1995-2006 & Cohort study & $\begin{array}{l}\text { Oral contraceptive, hormone } \\
\text { replacement therapy, age at } \\
\text { menarche, parity, age at first birth, } \\
\text { and age at menopause }\end{array}$ & $\begin{array}{l}\text { Sex, smoking status, baseline body } \\
\text { mass index, race, alcohol } \\
\text { consumption, and education }\end{array}$ \\
\hline $\begin{array}{l}\text { Horn-Ross } \\
{[14]}\end{array}$ & 2011 & USA & 1995-2008 & Cohort study & $\begin{array}{l}\text { Oral contraceptive, hormone } \\
\text { replacement therapy, age at } \\
\text { menarche, parity, age at first birth, } \\
\text { and menopausal status }\end{array}$ & $\begin{array}{l}\text { Sex, ethnicity, family history of } \\
\text { thyroid cancer, time since last } \\
\text { pregnancy, smoking, alcohol } \\
\text { consumption, physical inactivity, } \\
\text { height, adolescent cycle length, time } \\
\text { to regular menstruation, and age at } \\
\text { menarche }\end{array}$ \\
\hline $\begin{array}{l}\text { Meinhold } \\
{[18]}\end{array}$ & 2010 & USA & $1983-2006$ & Cohort study & $\begin{array}{l}\text { Oral contraceptive, hormone } \\
\text { replacement therapy, age at } \\
\text { menarche, parity, and menopausal } \\
\text { status }\end{array}$ & $\begin{array}{l}\text { Sex, birth year, smoking status, } \\
\text { body mass index, number of } \\
\text { personal radiographs to the head or } \\
\text { neck, and cumulative occupational } \\
\text { radiation dose }\end{array}$ \\
\hline Pham [23] & 2009 & Japan & 1988-1997 & Cohort study & $\begin{array}{l}\text { Hormone replacement therapy, age } \\
\text { at menarche, parity, age at first } \\
\text { birth, and age at menopause }\end{array}$ & $\begin{array}{l}\text { Sex, age at baseline, body mass } \\
\text { index, tobacco smoking status, } \\
\text { education level, history of diabetes, } \\
\text { and study area }\end{array}$ \\
\hline $\begin{array}{l}\text { Dorjgochoo } \\
{[10]}\end{array}$ & 2009 & China & 1996-2006 & Cohort study & Oral contraceptive & $\begin{array}{l}\text { Sex, education, age at menarche, } \\
\text { number of live births, cumulative } \\
\text { breast feeding months, body mass } \\
\text { index, exercised regularly in past } 5 \\
\text { years, smoking, menopausal status, } \\
\text { first-degree family history of cancer, } \\
\text { and other contraceptive methods }\end{array}$ \\
\hline Hannibal [12] & 2008 & Denmark & $1963-2000$ & Cohort study & Parity and age at first birth & $\begin{array}{l}\text { Sex, parity, age at cohort entry and } \\
\text { calendar year of cohort entry, and } \\
\text { age at first live birth }\end{array}$ \\
\hline Brindel [9] & 2008 & France & $1981-2004$ & PCC & $\begin{array}{l}\text { Age at menarche, parity, age at first } \\
\text { birth, menopausal status, age at } \\
\text { menopause, breastfeeding status, } \\
\text { and duration of breastfeeding }\end{array}$ & $\begin{array}{l}\text { Sex, educational level, height, body } \\
\text { mass index, and interviewer }\end{array}$ \\
\hline Wong [30] & 2006 & China & 1989-1998 & Cohort study & $\begin{array}{l}\text { Oral contraceptive, age at } \\
\text { menarche, parity, age at first birth, } \\
\text { age at menopause, breastfeeding } \\
\text { status, and duration of breastfeeding }\end{array}$ & $\begin{array}{l}\text { Sex, age, number of live births, and } \\
\text { age at first live delivery }\end{array}$ \\
\hline
\end{tabular}


TABle 1: Continued.

\begin{tabular}{|c|c|c|c|c|c|c|}
\hline First author & Year & Origin & Time & Study design ${ }^{\varsigma}$ & Hormonal or reproductive factors & Adjusted or matching criteria \\
\hline Truong [29] & 2005 & $\begin{array}{l}\text { New } \\
\text { Caledonia }\end{array}$ & 1993-1999 & PCC & $\begin{array}{l}\text { Oral contraceptive, hormone } \\
\text { replacement therapy, age at } \\
\text { menarche, and parity }\end{array}$ & $\begin{array}{l}\text { Sex, frequency, age, and residential } \\
\text { area }\end{array}$ \\
\hline Neale [21] & 2005 & Sweden & 1961-1996 & Cohort study & Age at first birth & $\begin{array}{l}\text { Sex, date of birth of the mother, } \\
\text { parity, and age at first birth }\end{array}$ \\
\hline $\begin{array}{l}\text { Navarro } \\
\text { Silvera [20] }\end{array}$ & 2005 & Canada & $1980-2000$ & Cohort study & $\begin{array}{l}\text { Oral contraceptive, hormone } \\
\text { replacement therapy, age at } \\
\text { menarche, parity, age at first birth, } \\
\text { and menopausal status }\end{array}$ & $\begin{array}{l}\text { Sex, age at first live birth, study } \\
\text { center and randomization group, } \\
\text { parity, and HRT use }\end{array}$ \\
\hline $\begin{array}{l}\text { Zivaljevic } \\
{[32]}\end{array}$ & 2003 & Serbia & $1996-2000$ & HCC & Parity & $\begin{array}{l}\text { Sex, age, place of residence, and } \\
\text { time of hospitalization }\end{array}$ \\
\hline Negri [22] & 2002 & Mixed & 1974-1992 & PCC & $\begin{array}{l}\text { Age at menarche, parity, age at first } \\
\text { birth, and menopausal status }\end{array}$ & Sex, age, ethnicity, and study center \\
\hline Memon [19] & 2002 & $\begin{array}{l}\text { Middle } \\
\text { East }\end{array}$ & 1981-1999 & PCC & $\begin{array}{l}\text { Oral contraceptive, hormone } \\
\text { replacement therapy, age at } \\
\text { menarche, parity, age at first birth, } \\
\text { and age at menopause }\end{array}$ & $\begin{array}{l}\text { Sex, year of birth, nationality, and } \\
\text { district of residence. }\end{array}$ \\
\hline Sakoda [26] & 2002 & USA & $1992-1998$ & PCC & $\begin{array}{l}\text { Age at menarche, menopausal } \\
\text { status, and age at menopause }\end{array}$ & $\begin{array}{l}\text { Sex, frequency, age, ethnicity, } \\
\text { education level, history of goiter or } \\
\text { nodules, history of radiation to the } \\
\text { head or neck, and family history of } \\
\text { proliferative thyroid disease }\end{array}$ \\
\hline Rossing [24] & 2000 & USA & 1988-1994 & PCC & $\begin{array}{l}\text { Age at menarche, parity, age at first } \\
\text { birth, and duration of breastfeeding }\end{array}$ & $\begin{array}{l}\text { Sex, age, county of residence, race, } \\
\text { and relative weight at age } 10\end{array}$ \\
\hline Mack [17] & 1999 & USA & $1980-1983$ & PCC & $\begin{array}{l}\text { Age at menarche, parity, age at first } \\
\text { birth, menopausal status, } \\
\text { breastfeeding status, and duration } \\
\text { of breastfeeding }\end{array}$ & $\begin{array}{l}\text { Sex, age, prior thyroid disease, and } \\
\text { number of births }\end{array}$ \\
\hline Takezaki [28] & 1996 & Japan & $1988-1993$ & $\mathrm{HCC}$ & $\begin{array}{l}\text { Age at menarche, parity, and age at } \\
\text { first birth }\end{array}$ & Sex, age, and year of visit \\
\hline Rossing [25] & 1998 & USA & 1988-1994 & PCC & $\begin{array}{l}\text { Oral contraceptive and hormone } \\
\text { replacement therapy }\end{array}$ & $\begin{array}{l}\text { Sex, age, county of residence, race, } \\
\text { and relative weight at age } 10\end{array}$ \\
\hline Galanti [11] & 1996 & $\begin{array}{l}\text { Sweden } \\
\text { and } \\
\text { Norway }\end{array}$ & $1985-1993$ & PCC & $\begin{array}{l}\text { Oral contraceptive, hormone } \\
\text { replacement therapy, parity, age at } \\
\text { first birth, and age at menopause }\end{array}$ & $\begin{array}{l}\text { Sex, frequency, year and month of } \\
\text { birth, type of menopause, and parity }\end{array}$ \\
\hline
\end{tabular}

the estimation of parity's effect on thyroid cancer risk $\left(I^{2}=\right.$ $61.2 \%, P<0.001)$. Stratified analysis by study design suggested that the main source of between-study heterogeneity resulted from studies in cohort design $\left(I^{2}=70.6 \%, P<\right.$ 0.001).

As suggested by Begg's funnel plots and Egger's test, there was no significant publication bias under all comparisons in the present meta-analysis (data not shown).

\section{Discussion}

Hormonal and reproductive factors have been implicated in the development of thyroid cancer, but the precise association and underlying molecular mechanisms have not yet been fully understood. A previous pooled analysis has investigated the association between female reproductive factors and thyroid cancer risk [39]. Unfortunately, only 17 epidemiological studies are included into the meta-analysis, which shows weak and equivocal association between some hormonal and menstrual cycle factors and thyroid cancer risk [39]. The present meta-analysis was based on 25 epidemiological studies on the association between hormonal and reproductive factors and thyroid cancer risk. No significant association was observed between thyroid cancer risk and common hormonal factors including oral contraceptive and hormone replacement therapy. Interestingly, older age at menopause might increase the risk of thyroid cancer, as suggested by the pooled RR in overall analysis ( RR $=1.24$, 95\% CI 1.00-1.53, $P=0.049$ ). Besides, longer duration of breast feeding was associated with moderately decreased risk of thyroid cancer, which had been suggested by the pooled analysis in cohort 
TABLE 2: Summary results for the association between hormonal and reproductive factors and thyroid cancer risk.

\begin{tabular}{|c|c|c|c|c|c|}
\hline \multirow{2}{*}{ Comparisons } & \multirow{2}{*}{${ }^{\mathrm{a}} \mathrm{RR}$} & \multirow{2}{*}{${ }^{\mathrm{b}} 95 \% \mathrm{CI}$} & \multirow{2}{*}{${ }^{\mathrm{c}} P$ value } & \multicolumn{2}{|c|}{ Tests for heterogeneity } \\
\hline & & & & $I^{2}(\%)$ & ${ }^{\mathrm{d}} P$ \\
\hline \multicolumn{6}{|l|}{ All } \\
\hline Oral contraceptive & 0.94 & $0.85-1.04$ & 0.215 & 36.0 & 0.095 \\
\hline Hormone replacement therapy & 1.04 & $0.91-1.19$ & 0.527 & 0 & 0.520 \\
\hline Age at menarche & 1.08 & $0.97-1.19$ & 0.142 & 0 & 0.486 \\
\hline Parity & 1.10 & $0.94-1.28$ & 0.234 & 61.2 & $<0.001$ \\
\hline Age at first birth & 1.07 & $0.95-2.20$ & 0.255 & 14.8 & 0.281 \\
\hline Menopausal status & 0.96 & $0.79-1.18$ & 0.727 & 4.9 & 0.394 \\
\hline Age at menopause & 1.24 & $1.00-1.53$ & 0.049 & 26.4 & 0.201 \\
\hline Duration of breast feeding & 0.84 & $0.65-1.08$ & 0.178 & 38.3 & 0.150 \\
\hline Breast feeding & 0.84 & $0.69-1.02$ & 0.080 & 4.9 & 0.368 \\
\hline \multicolumn{6}{|l|}{ Cohort studies } \\
\hline Oral contraceptive & 0.96 & $0.86-1.07$ & 0.448 & 39.5 & 0.104 \\
\hline Hormone replacement therapy & 1.05 & $0.91-1.20$ & 0.513 & 0 & 0.439 \\
\hline Age at menarche & 1.01 & $0.90-1.14$ & 0.808 & 16.1 & 0.299 \\
\hline Parity & 1.00 & $0.78-1.28$ & 0.993 & 70.6 & $<0.001$ \\
\hline Age at first birth & 1.04 & $0.92-1.18$ & 0.530 & 0 & 0.571 \\
\hline Menopausal status & 0.90 & $0.71-1.15$ & 0.418 & 26.6 & 0.252 \\
\hline Age at menopause & 1.3 & $1.04-1.63$ & 0.022 & 2.5 & 0.400 \\
\hline Duration of breast feeding & 0.70 & $0.51-0.95$ & 0.021 & 0 & 0.661 \\
\hline Breast feeding & 0.82 & $0.66-1.02$ & 0.078 & 0 & 0.442 \\
\hline \multicolumn{6}{|l|}{ PCC } \\
\hline Oral contraceptive & 0.89 & $0.73-1.08$ & 0.240 & 41.0 & 0.166 \\
\hline Hormone replacement therapy & 1.01 & $0.68-1.50$ & 0.962 & 6.0 & 0.363 \\
\hline Age at menarche & 1.28 & $1.04-1.57$ & 0.960 & 0 & 0.937 \\
\hline Parity & 1.00 & $0.93-1.07$ & 0.960 & 21.6 & 0.258 \\
\hline Age at first birth & 1.35 & $0.97-1.88$ & 0.072 & 42.3 & 0.123 \\
\hline Menopausal status & 1.10 & $0.78-1.57$ & 0.577 & 0 & 0.481 \\
\hline Age at menopause & 0.82 & $0.43-1.56$ & 0.554 & 44.0 & 0.147 \\
\hline Duration of breast feeding & 1.24 & $0.80-1.93$ & 0.332 & 28.2 & 0.248 \\
\hline Breast feeding & 0.92 & $0.60-1.41$ & 0.699 & 57.6 & 0.125 \\
\hline \multicolumn{6}{|l|}{$\mathrm{HCC}$} \\
\hline Parity & 2.30 & $1.31-4.04$ & 0.004 & 0 & 0.787 \\
\hline
\end{tabular}

studies $(\mathrm{RR}=0.7,95 \% \mathrm{CI} 0.51-0.95, P=0.021)$. Moreover, the pooled result in hospital-based case-control studies revealed that parous women were more susceptible to thyroid cancer than nulliparous women $(\mathrm{RR}=2.30,95 \% \mathrm{CI} 1.31-4.04, P=$ 0.004). Additionally, other reproductive factors including age at menarche, age at first birth, menopausal status, age at menopause, and breast feeding status did not modify the risk of thyroid cancer.

The risk of thyroid cancer in women increases at the time of puberty and declines after menopause [7, 40], supporting the hypothesis that menstrual cycle factors are involved in thyroid carcinogenesis. Elevated risk of thyroid cancer was related to the menopausal status when compared with premenopausal status [9]. Nonetheless, no significant association between the menopausal status, age at first birth, age at menarche, and age at menopause and thyroid cancer risk was observed $[16,18,23,27,31]$. It was worthwhile to note that menopausal females due to surgical factors were more susceptible to thyroid cancer compared with natural menopause ones [31], which might reflect enhanced medical surveillance of women who underwent surgical interventions for gynecological diseases symptoms. Similarly, we failed to identify any appreciable relationship of menstrual factors with thyroid cancer susceptibility. The discrepancies and underlying mechanisms need to be further elucidated by more relevant studies in the future. 


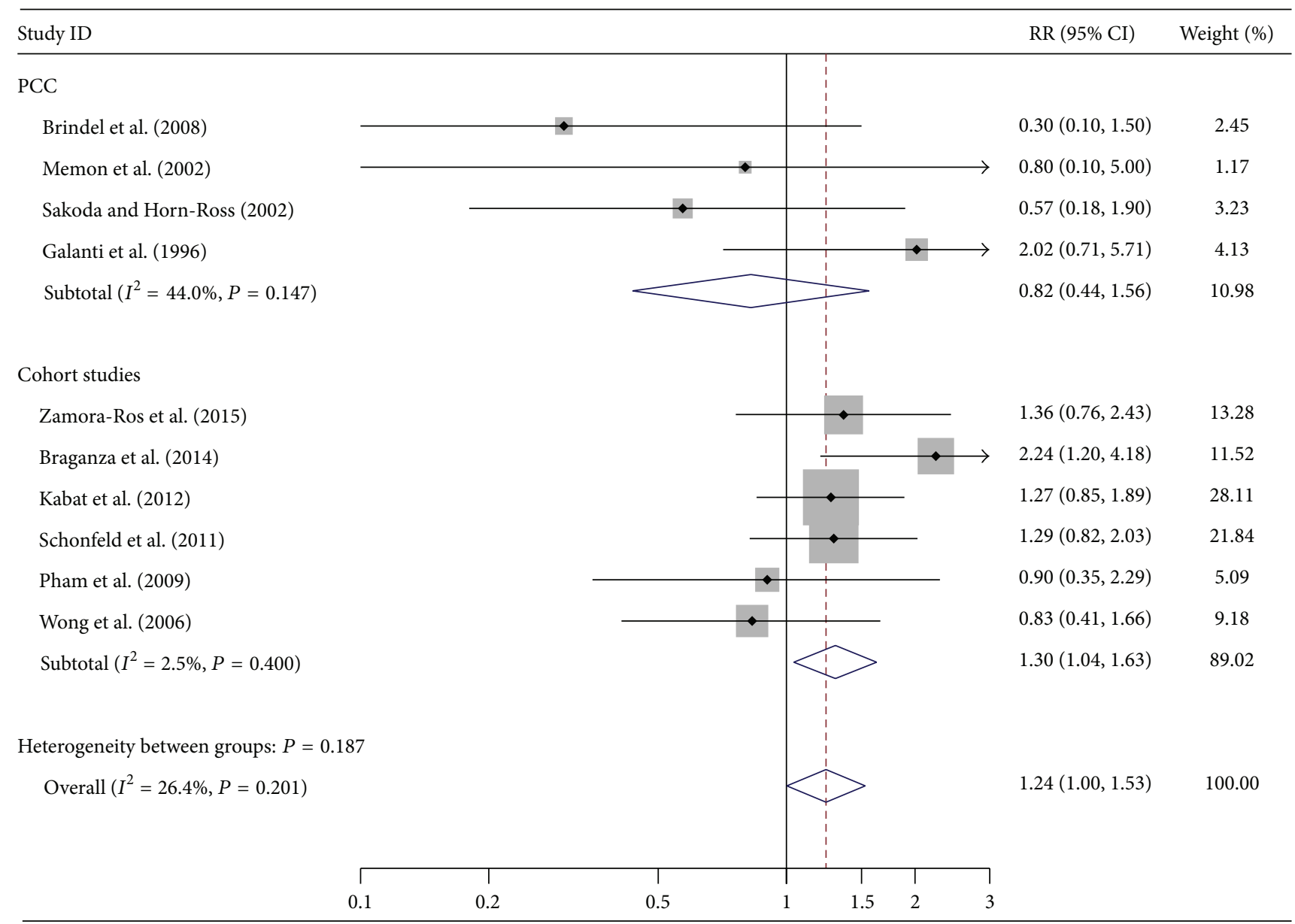

FIgURE 1: Forest plot for thyroid cancer risk related to age at menopause.

It has been well established that estrogen receptors are found in thyroid cancer tissue and confer effects on different molecular signaling pathways involved in the growth and function of thyroid [5, 41, 42]. Estrogens and estrogen receptors signals exert promoting effect on the growth of thyroid gland by enhancing levels of TSH [7]. A number of studies have suggested some hormonal related factors, for instance, oral contraceptive and hormone replacement therapy, which played different roles in the thyroid cancer risk $[8,23,27,31]$. Oral contraceptive seemed to play a protective role against thyroid cancer while an increased risk of thyroid cancer was found with the use of hormone replacement therapy demonstrated by Zamora-Ros et al. [31]. Similar findings were elucidated in a Caucasian cohort study [27]. Conversely, no modifying effects of oral contraceptive and hormone replacement therapy on the development of thyroid cancer were in another independent cohort study $[8,23]$. The contradictory findings may be attributed to different study design, use of contraceptive and hormone replacement therapy, ethnicity, and adjusted or matching criteria in individual epidemiological studies. Our study showed no appreciable roles of hormonal factors in thyroid carcinogenesis, as suggested by both overall analysis and stratified analysis according to study design. More future studies are warranted to further estimate the association between hormonal-related factors and thyroid cancer risk.

The effect of breastfeeding on thyroid cancer risk is still not clear. Kabat and colleagues demonstrated that duration of breastfeeding did not alter the susceptibility to thyroid cancer [16]. However, Mack et al. provided the evidence that longer duration of breastfeeding was negatively associated with the risk of thyroid cancer risk, suggesting a protective role of breastfeeding in thyroid carcinogenesis [17]. Similarly, the pooled RRs in all cohort studies implicated that longer duration of breast feeding was associated with moderately reduced risk of thyroid cancer. Nevertheless, there was no significant relationship between breastfeeding status and thyroid carcinogenesis in pooled analyses of total studies and population-based case-control ones. Thus, the moderate association might be a chance resulting from potential bias in the present meta-analysis. To better understand the role of breastfeeding status in the thyroid cancer development, more relevant studies with high quality are warranted. 


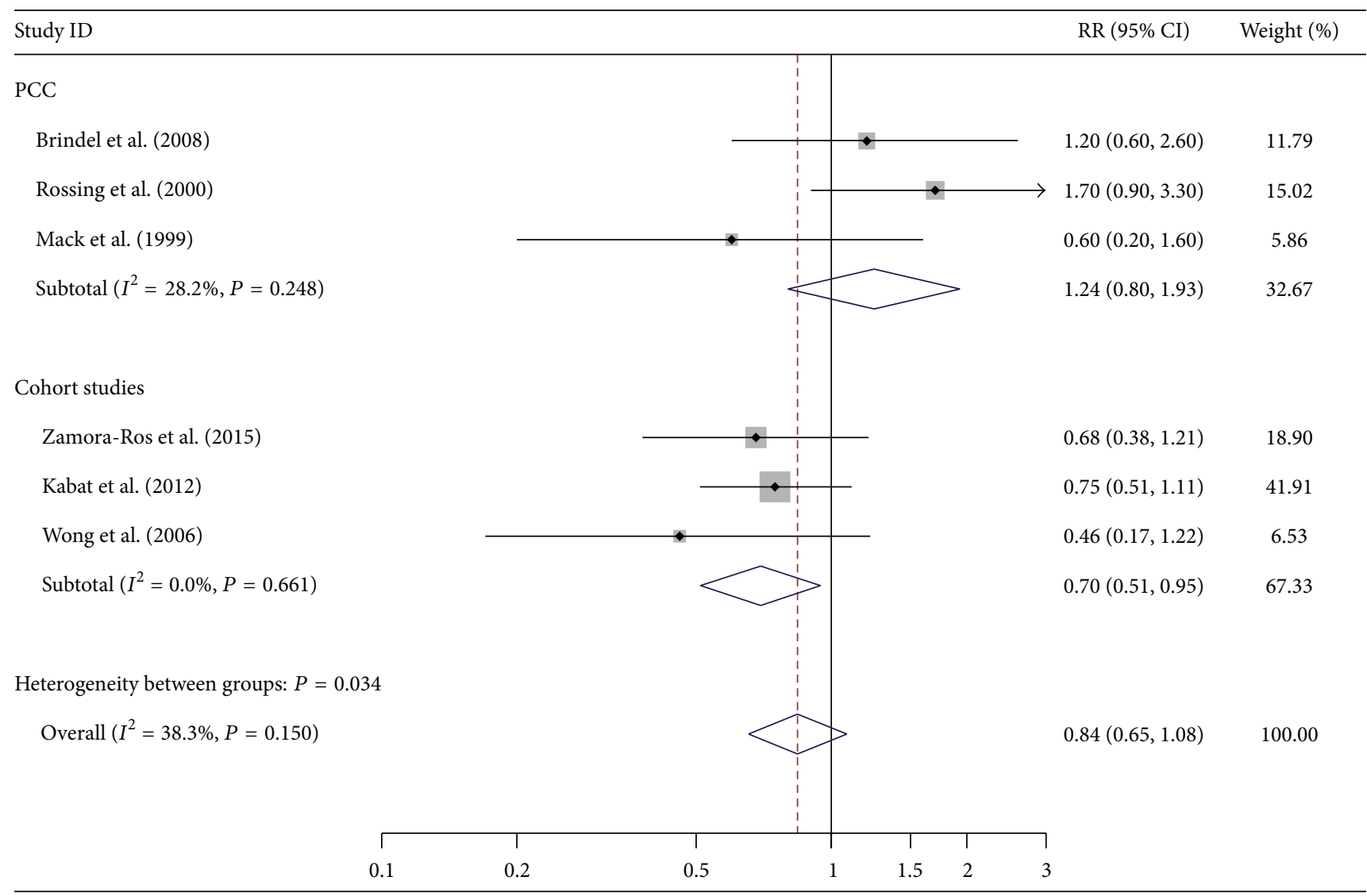

FIGURE 2: Forest plot for thyroid cancer risk related to duration of breastfeeding.

The status of parity conferred diverse effects on thyroid cancer risk in different populations. A recent study by Braganza et al. showed that parous women were at an elevated risk of thyroid cancer, as suggested by a recent epidemiological study [8]. Interestingly, for any given level of parity, there was about twofold increased risk of thyroid cancer among women with the age at last pregnancy larger than 30 years [19]. Unlike the findings mentioned above, no appreciable association was suggested between parity and the susceptibility to thyroid cancer among a Caucasian population [27]. In the current meta-analysis, significantly positive association was only demonstrated in the pooled analysis of two hospital-based case-control studies. Although age seemed to influence roles of reproductive factors in thyroid carcinogenesis, we failed to find appreciable association for age at first birth, age at menarche, and age at menopause. In addition, the pooled results, particularly in hospital-based case-control studies, must be interpreted with caution due to limited sample size and insufficient statistical power in current research.

Age is a main confounding factor for the association between hormonal and reproductive factors and thyroid cancer risk [19]. We failed to perform stratified analysis by age or other confounding factors, such as dosage and usage of hormonal drugs, the reason of menopause, number of live births, outcome of first pregnancy, and history of miscarriage, because of unavailable information about these items in single studies. Consequently, the association between hormonal and reproductive factors and thyroid cancer risk should be further investigated in view of above-mentioned confounding factors.

\section{Conclusions}

The current meta-analysis suggests that older age at menopause and parity are associated with increased risk of thyroid cancer, while longer duration of breast feeding plays a protective role against this cancer. In addition, the precise association needs further investigation by more epidemiological studies with sufficient statistical power in the future.

\section{Conflict of Interests}

The authors declare no conflict of interests. 


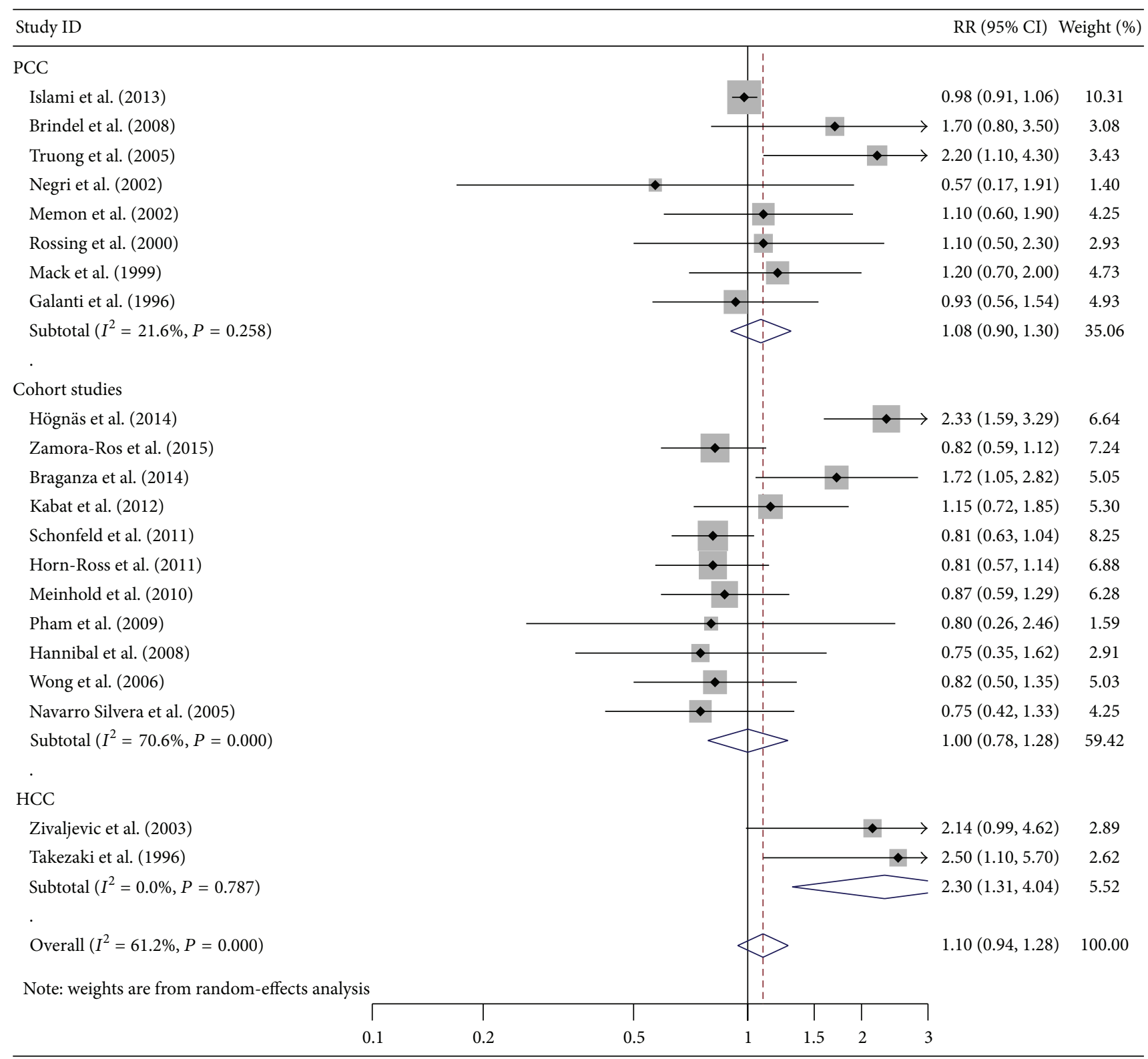

FIGURE 3: Forest plot for thyroid cancer risk related to parity.

\section{References}

[1] L. S. Ward, "Thyroid tumors: are we unveiling the puzzle?" Endocrine-Related Cancer, vol. 21, no. 5, pp. E7-E8, 2014.

[2] E. Ron, "Cancer risks from medical radiation," Health Physics, vol. 85, no. 1, pp. 47-59, 2003.

[3] M. Zane, V. Catalano, E. Scavo et al., "Estrogens and stem cells in thyroid cancer," Frontiers in Endocrinology, vol. 5, article 124, 2014.

[4] G. G. Chen, A. C. Vlantis, Q. Zeng, and C. A. van Hasselt, "Regulation of cell growth by estrogen signaling and potential targets in thyroid cancer," Current Cancer Drug Targets, vol. 8, no. 5, pp. 367-377, 2008.
[5] P. K. Chaudhuri and R. Prinz, "Estrogen receptor in normal and neoplastic human thyroid tissue," American Journal of Otolaryngology, vol. 10, no. 5, pp. 322-326, 1989.

[6] E. D. Williams, "TSH and thyroid cancer," Hormone and Metabolic Research. Supplement, vol. 23, pp. 72-75, 1990.

[7] R. Tahboub and B. M. Arafah, "Sex steroids and the thyroid," Best Practice and Research: Clinical Endocrinology and Metabolism, vol. 23, no. 6, pp. 769-780, 2009.

[8] M. Z. Braganza, A. B. de González, S. J. Schonfeld, N. Wentzensen, A. V. Brenner, and C. M. Kitahara, "Benign breast and gynecologic conditions, reproductive and hormonal factors, and risk of thyroid cancer," Cancer Prevention Research, vol. 7, no. 4, pp. 418-425, 2014. 
[9] P. Brindel, F. Doyon, F. Rachédi et al., "Menstrual and reproductive factors in the risk of differentiated thyroid carcinoma in native women in French Polynesia: a population-based casecontrol study," American Journal of Epidemiology, vol. 167, no. 2, pp. 219-229, 2008.

[10] T. Dorjgochoo, X.-O. Shu, H.-L. Li et al., "Use of oral contraceptives, intrauterine devices and tubal sterilization and cancer risk in a large prospective study, from 1996 to 2006," International Journal of Cancer, vol. 124, no. 10, pp. 2442-2449, 2009.

[11] M. R. Galanti, L. Hansson, E. Lund et al., "Reproductive history and cigarette smoking as risk factors for thyroid cancer in women: a population-based case-control study," Cancer Epidemiology Biomarkers and Prevention, vol. 5, no. 6, pp. 425431, 1996.

[12] C. G. Hannibal, A. Jensen, H. Sharif, and S. K. Kjaer, "Risk of thyroid cancer after exposure to fertility drugs: results from a large Danish cohort study," Human Reproduction, vol. 23, no. 2, pp. 451-456, 2008.

[13] E. Högnäs, A. Kauppila, E. Pukkala, and J. S. Tapanainen, "Cancer risk in women with 10 or more deliveries," Obstetrics and Gynecology, vol. 123, no. 4, pp. 811-816, 2014.

[14] P. L. Horn-Ross, A. J. Canchola, H. Ma, P. Reynolds, and L. Bernstein, "Hormonal factors and the risk of papillary thyroid cancer in the California teachers study cohort," Cancer Epidemiology Biomarkers and Prevention, vol. 20, no. 8, pp. 17511759, 2011.

[15] F. Islami, Y. Cao, F. Kamangar et al., "Reproductive factors and risk of esophageal squamous cell carcinoma in northern Iran: a case-control study in a high-risk area and literature review," European Journal of Cancer Prevention, vol. 22, no. 5, pp. 461466, 2013.

[16] G. C. Kabat, M. Y. Kim, J. Wactawski-Wende, D. Lane, S. Wassertheil-Smoller, and T. E. Rohan, "Menstrual and reproductive factors, exogenous hormone use, and risk of thyroid carcinoma in postmenopausal women," Cancer Causes and Control, vol. 23, no. 12, pp. 2031-2040, 2012.

[17] W. J. Mack, S. Preston-Martin, L. Bernstein, D. Qian, and M. Xiang, "Reproductive and hormonal risk factors for thyroid cancer in Los Angeles County females," Cancer Epidemiology Biomarkers and Prevention, vol. 8, no. 11, pp. 991-997, 1999.

[18] C. L. Meinhold, E. Ron, S. J. Schonfeld et al., "Nonradiation risk factors for thyroid cancer in the US radiologic technologists study," American Journal of Epidemiology, vol. 171, no. 2, pp. 242-252, 2010.

[19] A. Memon, M. Darif, K. Al-Saleh, and A. Suresh, "Epidemiology of reproductive and hormonal factors in thyroid cancer: Evidence from a case-control study in the Middle East," International Journal of Cancer, vol. 97, no. 1, pp. 82-89, 2002.

[20] S. A. Navarro Silvera, A. B. Miller, and T. E. Rohan, "Risk factors for thyroid cancer: a prospective cohort study," International Journal of Cancer, vol. 116, no. 3, pp. 433-438, 2005.

[21] R. E. Neale, S. Darlington, M. F. G. Murphy, P. B. S. Silcocks, D. M. Purdie, and M. Talbäck, "The effects of twins, parity and age at first birth on cancer risk in Swedish women," Twin Research and Human Genetics, vol. 8, no. 2, pp. 156-162, 2005.

[22] E. Negri, E. Ron, S. Franceschi et al., "Risk factors for medullary thyroid carcinoma: a pooled analysis," Cancer Causes and Control, vol. 13, no. 4, pp. 365-372, 2002.

[23] T.-M. Pham, Y. Fujino, H. Mikami et al., "Reproductive and menstrual factors and thyroid cancer among Japanese women: the Japan collaborative cohort study," Journal of Women's Health, vol. 18, no. 3, pp. 331-335, 2009.
[24] M. A. Rossing, L. F. Voigt, K. G. Wicklund, and J. R. Daling, "Reproductive factors and risk of papillary thyroid cancer in women," The American Journal of Epidemiology, vol. 151, no. 8, pp. 765-772, 2000.

[25] M. A. Rossing, L. F. Voigt, K. G. Wicklund, M. Williams, and J. R. Daling, "Use of exogenous hormones and risk of papillary thyroid cancer (Washington, United States)," Cancer Causes and Control, vol. 9, no. 3, pp. 341-349, 1998.

[26] L. C. Sakoda and P. L. Horn-Ross, "Reproductive and menstrual history and papillary thyroid cancer risk: the San Francisco Bay Area thyroid cancer study," Cancer Epidemiology Biomarkers and Prevention, vol. 11, no. 1, pp. 51-57, 2002.

[27] S. J. Schonfeld, E. Ron, C. M. Kitahara et al., "Hormonal and reproductive factors and risk of postmenopausal thyroid cancer in the NIH-AARP Diet and Health Study," Cancer Epidemiology, vol. 35, no. 6, pp. e85-e90, 2011.

[28] T. Takezaki, K. Hirose, M. Inoue et al., "Risk factors of thyroid cancer among women in Tokai, Japan," Journal of Epidemiology, vol. 6, no. 3, pp. 140-147, 1996.

[29] T. Truong, L. Orsi, D. Dubourdieu, Y. Rougier, D. Hémon, and P. Guénel, "Role of goiter and of menstrual and reproductive factors in thyroid cancer: a population-based case-control study in New Caledonia (South Pacific), a very high incidence area," The American Journal of Epidemiology, vol. 161, no. 11, pp. 10561065, 2005.

[30] E. Y. Wong, R. Ray, D. L. Gao et al., "Reproductive history, occupational exposures, and thyroid cancer risk among women textile workers in Shanghai, China," International Archives of Occupational and Environmental Health, vol. 79, no. 3, pp. 251258, 2006.

[31] R. Zamora-Ros, S. Rinaldi, C. Biessy et al., "Reproductive and menstrual factors and risk of differentiated thyroid carcinoma: the EPIC study," International Journal of Cancer, vol. 136, no. 5, pp. 1218-1227, 2015.

[32] V. Zivaljevic, H. Vlajinac, R. Jankovic et al., "Case-control study of female thyroid cancer-menstrual, reproductive and hormonal factors," European Journal of Cancer Prevention, vol. 12, no. 1, pp. 63-66, 2003.

[33] W. G. Cochran, "The comparison of percentages in matched samples," Biometrika, vol. 37, pp. 256-266, 1950.

[34] J. P. T. Higgins, S. G. Thompson, J. J. Deeks, and D. G. Altman, "Measuring inconsistency in meta-analyses," British Medical Journal, vol. 327, no. 7414, pp. 557-560, 2003.

[35] R. DerSimonian and N. Laird, "Meta-analysis in clinical trials," Controlled Clinical Trials, vol. 7, no. 3, pp. 177-188, 1986.

[36] N. Mantel and W. Haenszel, "Statistical aspects of the analysis of data from retrospective studies of disease," Journal of the National Cancer Institute, vol. 22, no. 4, pp. 719-748, 1959.

[37] M. Egger, G. D. Smith, M. Schneider, and C. Minder, "Bias in meta-analysis detected by a simple, graphical test," British Medical Journal, vol. 315, no. 7109, pp. 629-634, 1997.

[38] A. E. Stuck, L. Z. Rubenstein, and D. Wieland, "Bias in meta-analysis detected by a simple, graphical test. Asymmetry detected in funnel plot was probably due to true heterogeneity," BMJ (Clinical research ed.), vol. 316, no. 7129, pp. 469-471, 1998.

[39] E. Peterson, P. De, and R. Nuttall, "BMI, diet and female reproductive factors as risks for thyroid cancer: a systematic review," PLoS ONE, vol. 7, no. 1, Article ID e29177, 2012.

[40] P. H. Bisschop, A. W. Toorians, E. Edert, W. M. Wiersinga, L. J. Gooren, and E. Fliers, "The effects of sex-steroid administration on the pituitary-thyroid axis in transsexuals," European Journal of Endocrinology, vol. 155, no. 1, pp. 11-16, 2006. 
[41] N. Takeichi, H. Ito, R. Haruta, T. Matsuyama, K. Dohi, and E. Tahara, "Relation between estrogen receptor and malignancy of thyroid cancer," Japanese Journal of Cancer Research, vol. 82, no. 1, pp. 19-22, 1991.

[42] S. Rajoria, R. Suriano, A. L. George et al., "Estrogen activity as a preventive and therapeutic target in thyroid cancer," Biomedicine and Pharmacotherapy, vol. 66, no. 2, pp. 151-158, 2012. 


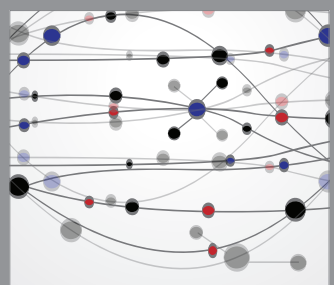

The Scientific World Journal
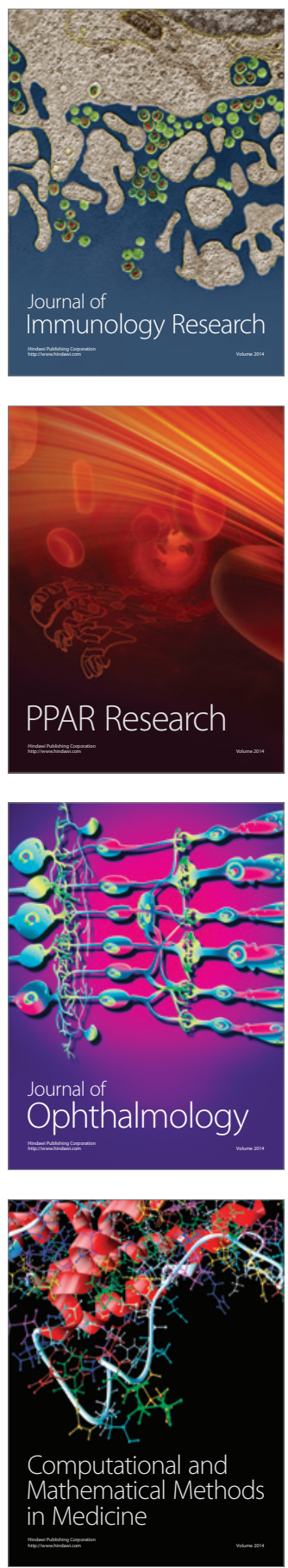

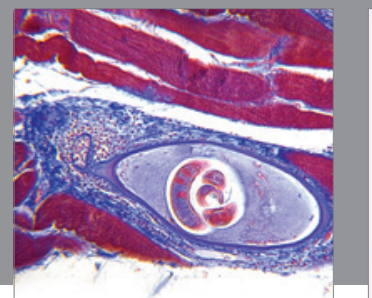

Gastroenterology

Research and Practice
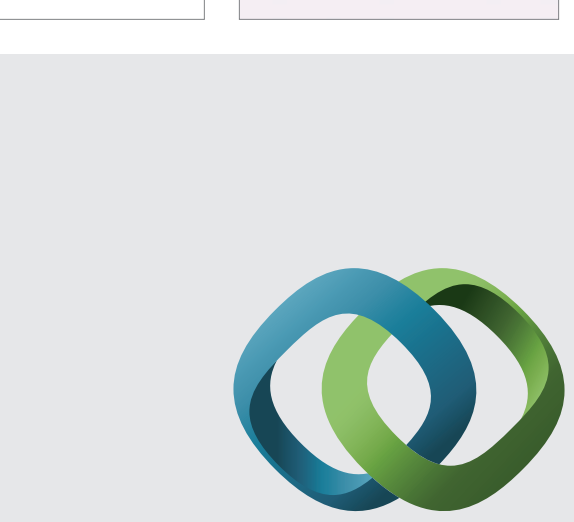

\section{Hindawi}

Submit your manuscripts at

http://www.hindawi.com
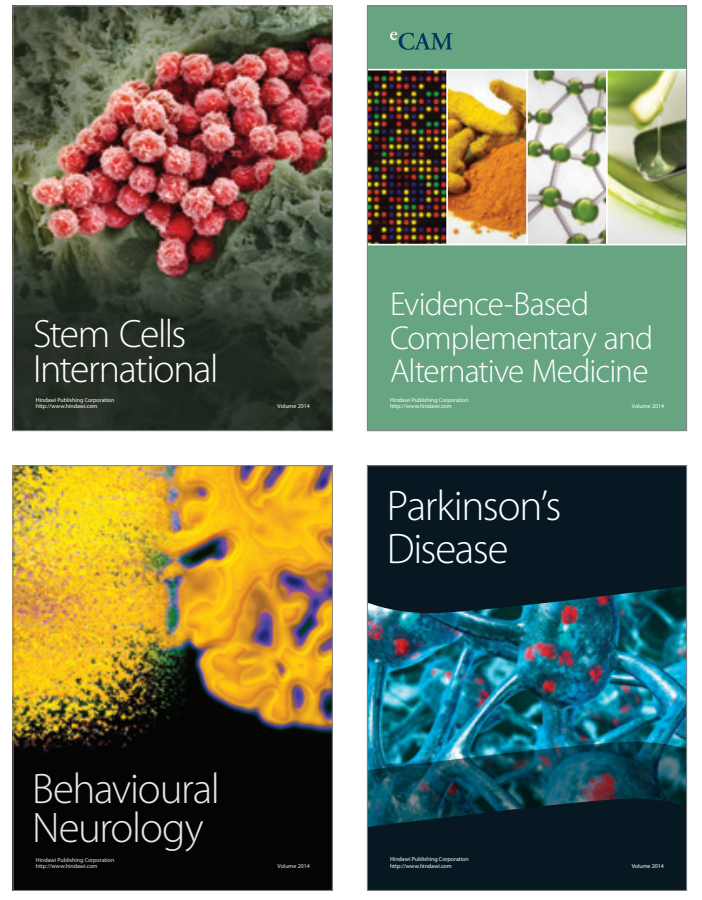
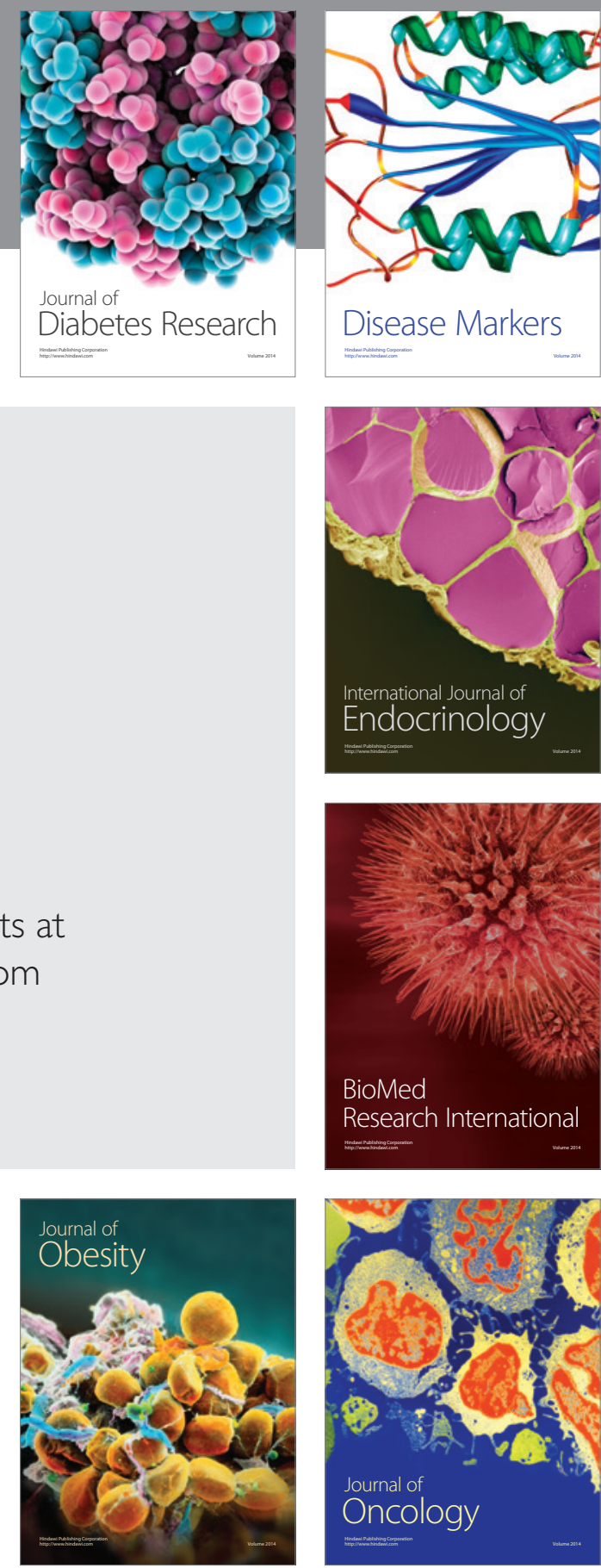

Disease Markers
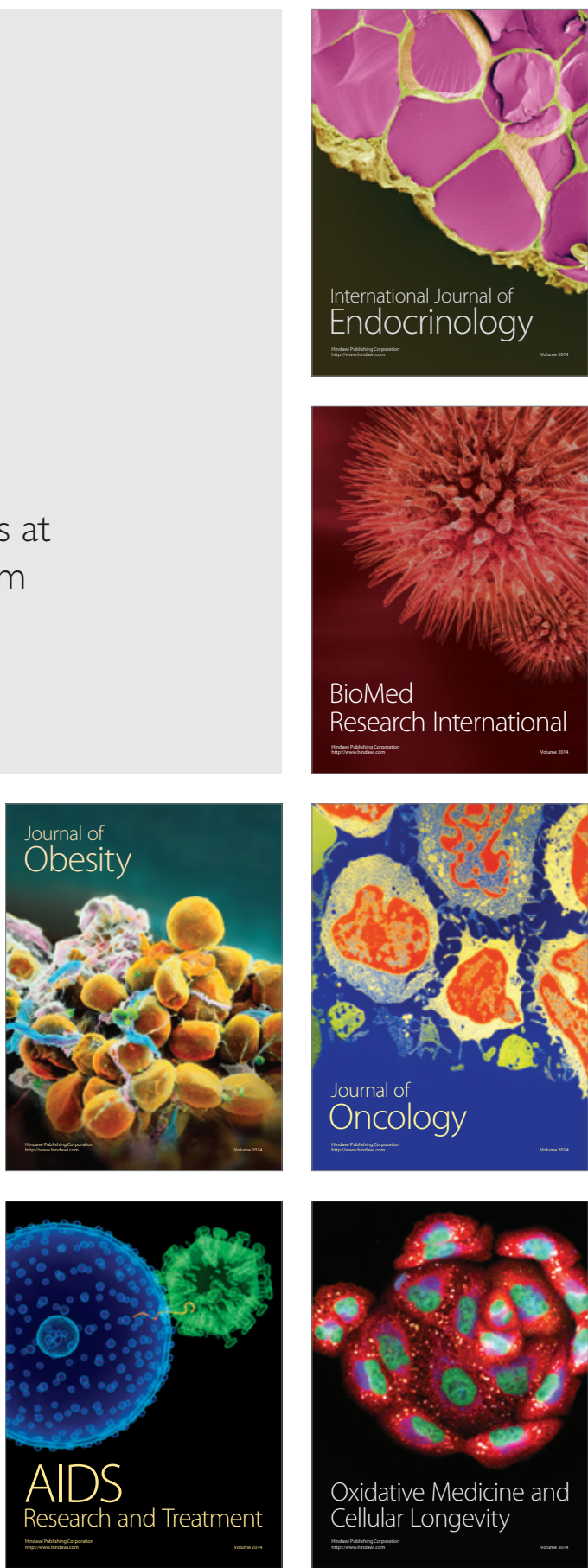